\section{Losses no worry to Boston}

\section{Boston}

Boston University's controversial investment in a small biotechnology company called Seragen Inc. is drawing new criticism as reports surface that the university will write off another $\$ 16$ million of its sizeable stake in the company. The latest revelation means that the total losses written off by the university are now greater than the initial \$25 million the university spent to acquire a majority interest in the company in 1987.

With no immediate prospect of products or revenue from the fledgling company and with Boston University covering the company's entire operating costs in the form of 'loans' totalling approximately $\$ 1$ million a month, the Boston University Seragen situation is a financial arrangement without precedent or peer in the realm of academic investment. $\$ 60$ million in university funds has been invested in the company since 1987 - a sum equal to nearly a third of the university's endowment.

But university representatives call the recent write-off merely a prudent, "conservative accounting procedure", and add that they remain confident that their investment will ultimately pay off. Boston University's controversial president, John Silber, widely perceived to have staked his reputation on the investment, has repeatedly defended the company's prospects, calling it a "future Xerox", and predicting revenues of billions within the decade.

Nonetheless, many Boston University faculty members, including the retired dean of the university's business school, have publicly called the arrangement "crazy" and "irresponsible" and accused Silber and other university administrators of siphoning off much-needed university dollars to support a risky commercial venture.

What makes the situation so extraordinary is not only the relative size of such a highly speculative investment, but the fact that Boston University, as 70 per cent owner of the company, has committed itself to supporting the firm indefinitely out of 'discretionary' university funds. The university has, in effect, taken full financial responsibility for a commercial venture - one that currently employs 100 people. And even if it does succeed, may not turn a profit for many years.

Although a risky investment for a university, Seragen's research aims are considered it sound. The company has patented a method to produce hybrid proteins using a 'tamed' diphtheria toxin. The hybrid proteins - so-called chimaeric receptor toxins - are designed to target particular receptor cells for the treament of autoimmune diseases, such as certain forms of cancer, while leaving other cells in the body unharmed.

Seragen has pioneered the use of the diphtheria toxin, but the more general research strategy has attracted the attention of many companies.

Thasia Woodworth, Seragen's clinical and regulatory affairs director, stresses that the company has products in "every phase of the pipeline", but only one potential product is currently undergoing clinical trials in humans. The drug, called Leukocytoxin- $\mathrm{L}$, is designed to treat adult $\mathrm{T}$-cell leukaemia by pairing the altered diphtheria toxin with the interleukin-2 binding site. The result, Seragen hopes, is a protein that will attack and kill altered lymphocytes. Related research at the company employs the hybrid molecule technology to bring the altered diphtheria toxin to kill cells causing malignant melanoma, and those implicated in the rejection of transplanted organs.

The Seragen investment renews questions about the extent to which a university ought to support the commercialization of research.

Seragen's connections with Boston University are said to date back to the early 1980 s when a small company was founded with funds from the university's venture capital fund. The controversial part of Boston University's investment, however, began in 1987 when, apparently at Silber's forceful urging, the school acquired a majority stake in the company from a Norwegian pharmaceutical company wishing to sell off its investment in Seragen. Boston University's purchase came just two months before the stock market crash in which biotechnology companies were particularly badly hit.

At least as controversial as the Seragen investment is Silber himself, who is now unofficially considered a conservative democratic candidate in the upcoming gubernatorial race in Massachusetts. Silber's caustic and authoritarian style has earned him many bitter enemies inside and outside the university. Nonetheless, he is credited with many achievements during his 18-year tenure as president of Boston University. Unquestionably, the school was in poor shape when he took over. A chronic operating deficit was quickly corrected, and the school's endowment, which in 1970 stood at a mere $\$ 19$ million, has since grown nine-fold. Silber even managed to attract both US President Bush and French President François Mitterrand to speak at the university's 150th anniversary celebrations.

Yet even some Silber supporters remain highly sceptical of the Seragen deal. And official university justifications of the arrangement have been criticized as too defensive and farfetched. University vice president John Westling, for instance, says adamantly that "no endowment funds have ever been used in any of the transactions with Seragen". But critics, such as Rich Cowan, speaking for the National Coalition for Universities in the Public Interest, counter that the distinction is largely semantic: the 'discretionary funds' used in the Seragen investment, they say, could have been used to increase the school's endowment by 30 per cent. "Whether technically endowment funds or not", says Cowan, "the school could have endowed five or six new faculty positions instead of funding a commercial venture." But Westling defends the Seragen investment as an example to university researchers that the school "actively supports them in bringing the fruits of their research to market". Without arrangements such as the Seragen investment, Westling contends, universities in the United States will "lose the ability to attract and sustain top researchers in the academy", a prospect he says would deliver an "extremely damaging blow" to the nation's scientific enterprise.

Entrepreneurial wizardry or financial folly, the Seragen arrangement will remain controversial. Despite growing fears that the university is like a drug addict with a " $\$ 30,000$-a-day biotech habit", as one critic has put it, university officials such as Westling and Silber remain unshakeable in their devotion to the biotechnology company. Controversial or not, Westling states the university position unequivocally: "As it stands now", he says, "we have no intention of getting out."

Seth Shulman

\section{AUSTRALIA}

\section{New CSIRO man to stress industrial links}

\section{Sydney}

JoHN Stocker has been named as the new chief executive of Australia's Commonwealth Scientific and Industrial Research Organisation (CSIRO). Stocker is at present managing director of the Australian Medical Research and Development Corporation (AMRAD) and will take over from Keith Boardman on 5 March 1990.

Stocker's background is in industry, fitting in well with CSIRO's conviction that science must be made profitable. "CSIRO's biggest problem is in its dialogue with industry", Stocker says, "Scientists, until now, have had difficulty in convincing industry of the relevance of science." Stocker is also concerned with motivating CSIRO scientists and says he will be "looking at the introduction of performance related awards". Tania Ewing - Australia features in this week's Commentary, page 203. 